\title{
IMPLEMENTASI MODEL-VIEW-CONTROLLER (MVC) PADA UJIAN ONLINE MELALUI PENERAPAN FRAMEWORK CODEIGNITER
}

\author{
Yohanes Rasuliano Laberto Kelen a, \\ Benyamin Jago Belalawe ${ }^{b}$ \\ ${ }^{a}$ STIKOM Uyelindo Kupang, Kayu Putih - NTT, \\ ${ }^{\text {b }}$ STIKOM Uyelindo Kupang, Kayu Putih - NTT \\ aexchellenz@live.com, ${ }^{\mathrm{b}}$ pbcrewx@gmail.com
}

\begin{abstract}
ABSTRAK
Pendidikan termasuk salah satu bidang yang turut mengalami peningkatan dalam konteks penyelenggaraan ujian. Ujian konvensional yang masih menggunakan kertas perlahan-lahan mulai ditinggalkan. Penyelenggaraan ujian yang terkomputerisasi pun menjadi terobosan yang bukan lagi baru di zaman ini.

Model, view, controller (MVC) merupakan sebuah arsitektur pengembangan aplikasi yang menekankan kepada 3 komponen penting. Ketiga komponen tersebut masing-masing memiliki fokus perhatian, tanggung jawab dan logika sehingga mempercepat kinerjanya. Framework codeigniter merupakan salah satu framework terkenal yang sudah mendukung MVC. Dengan framework codeigniter, pengembangan aplikasi web dapat dilakukan dengan cepat. Sekolah Menengah Kejuruan Informatika Uyelindo Kupang pun merupakan salah satu sekolah dengan basis kejuruan informatika komputer. Sekolah ini dapat menerapkan ujian yang terkomputerisasi dengan sebuah sistem yang dinamakan sistem ujian online. Sistem ini dibangun dengan framework codeigniter.

Hasil implementasinya adalah sebuah sistem ujian yang berbasis web dengan framework codeigniter yang dapat mempermudah guru dan siswa dalam melaksanakan ujian yang fleksibel. Ujian ini dapat dilaksanakan dimana saja dengan waktu yang sudah ditetapkan oleh guru dan tidak lagi menggunakan kertas sebagai media pelaksanaan ujian. Harapan dengan adanya sistem ujian seperti ini, proses tatap muka di kelas menjadi lebih efektif dan guru dapat mengetahui kemampuan siswa dengan kuis yang bisa dikerjakan dari rumah.
\end{abstract}

Keywords : codeigniter, framework, model view controller, MVC, ujian online.

\section{PENDAHULUAN}

Peranan teknologi informasi sudah berkembang sedemikian pesat di segala bidang kehidupan manusia. Pendidikan termasuk salah satu bidang yang turut mengalami peningkatan dalam konteks penyelenggaraan ujian. Kecepatan, kepraktisan dan juga kemudahan yang tidak ditemukan pada ujian yang masih menggunakan kertas dapat bergeser ke arah komputerisasi dengan menerapkan ujian online.

Dengan penyelenggaraan ujian yang terkomputerisasi, diharapkan terjadi penekanan biaya terhadap penggunaan sumber daya kertas. Pelaksanaan ujian online yang terhubung dengan jaringan internet pun menjadi lebih fleksibel karena bisa dilakukan di mana saja dan kapan saja. Siswa pun dapat menguji kemampuan belajar akan mata pelajaran dan secara tidak langsung efektifitas guru dalam pengajaran di sekolah menjadi lebih baik.

Model, view, controller (MVC) merupakan sebuah arsitektur pengembangan aplikasi yang menekankan kepada 3 komponen penting. Ketiga komponen tersebut masing-masing memiliki fokus perhatian, tanggung jawab dan logika sehingga mempercepat kinerjanya (Harianja, 2010). Framework Codeigniter merupakan salah satu framework terkenal yang sudah mendukung MVC. Dengan framework codeigniter, pengembangan aplikasi web dapat dilakukan dengan cepat. 


\section{METODE PENELITIAN}

Metodologi adalah proses mendapat data sampai dengan pembuatan perancangan program yang akan dirancang atau dibangun. Dalam melakukan penelitian penulis menggunakan beberapa metode untuk mendapatkan data yaitu: metode kepustakaan, yakni mencari literatur atau sumber-sumber pustaka pendukung yang mampu memberikan informasi yang memadai; metode wawancara, yakni melakukan pembicaraan dengan pihak terkait.

\section{A. Tinjauan umum software}

1) Hypertext Preprocessor

Menurut Peranginangin (2006), PHP singkatan dari Hypertext Preprocessor yang digunakan sebagai bahasa script server-side dalam pengembangan web yang disisipkan pada dokumen html. Penggunaan PHP memungkinkan web dapat dibuat dinamis sehingga maintenance situs web tersebut menjadi lebih mudah dan efisien. PHP merupakan software open-source yang disebarkan dan dilisensikan secara gratis.

2) MySQL

Kadir (2010) menyatakan MySQL tergolong sebagai DBMS (Database Management System). Perangkat lunak ini bermanfaat untuk mengelola data dengan cara yang sangat fleksibel dan cepat.

\section{B. Tinjauan pustaka}

\section{1) MVC}

MVC (Model, View dan Controller) yang merupakan sebuah arsitektur untuk membuat sebuah program. Tujuan dari pembagian program ke dalam tiga bagian besar ini adalah untuk memisahkan fokus perhatian, tanggung jawab, dan logika ke dalam bagian masing-masing. (Harianja, 2010).

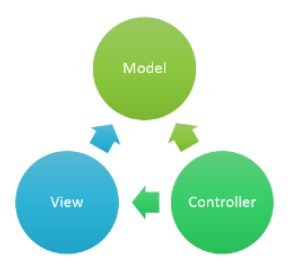

Gambar 1. Model, view, controller

a) Model adalah bagian dari aplikasi yang mengimplementasikan logika untuk domain data aplikasi. Umumnya, objek model digunakan untuk mengambil data dari database atau menyimpan data ke dalam database.

b) View adalah komponen yang menampilkan antarmuka (user interface) untuk pengguna aplikasi. Antarmuka ini dibuat berdasarkan data dari model.

c) Controller merupakan komponen yang digunakan untuk menangani interaksi pengguna, bekerja dengan model, dan memilih view mana yang digunakan untuk me-render data.

\section{2) Framework}

Framework adalah kumpulan kode program yang disimpan pada file yang berbeda yang dapat menyederhanakan operasi yang berulang-ulang. Kelebihan dengan adanya framework adalah dapat melakukan pengembangan aplikasi menjadi seragam, dimana pengembang dituntut untuk mengikuti alur kerja yang ditetapkan oleh framework. (Harianja, 2010).

\section{3) Codeigniter}

Sidik (2012) menyatakan bahwa codeigniter (CI) adalah framework pengembangan aplikasi (application development framework) yang memiliki suatu kerangka yang sistematis untuk bekerja atau membuat program dengan menggunakan PHP. Codeigniter menyediakan sekumpulan library yang banyak untuk keperluan menyelesaikan pekerjaan yang umum, dengan menggunakan antarmuka dan struktur logika yang sederhana untuk mengakses library-nya.

a) index.php berlaku sebagai controller di depan, yang menginisiasikan sumber 
daya yang dibutuhkan untuk menjalankan codeigniter,

b) Router akan memeriksa request HTTP untuk menentukan apa yang harus dilakukan dengan request tersebut,

c) Jika ada file cache, maka file cache langsung dikirimkan kepada browser, dengan memotong eksekusi sistem normal,

d) Untuk keamanan, sebelum suatu aplikasi controller dipanggil, request HTTP dan data yang dikirimkan oleh pengguna disaring (filter) terlebih dahulu,

e) Controller akan memuat model, library, helper, dan sumber daya lainnya yang diperlukan untuk memproses request tersebut.

f) View terakhir di-render kemudian dikirimkan kepada browser untuk dilihat. Jika caching didefinisikan, maka view akan di-cache terlebih dahulu, setelah itu baru dikirimkan kepada browser.

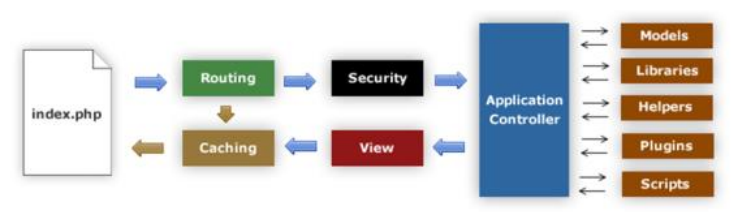

Gambar 2. Flowchart codeigniter mengimplementasikan MVC

\section{Perancangan sistem}

Unified Modeling Language (UML) adalah salah satu alat bantu yang sangat handal di dunia pengembangan sistem. UML menyediakan bahasa pemodelan visual yang memungkinkan bagi pengembang sistem untuk membuat cetak biru atas visi mereka dalam bentuk baku, mudah dimengerti serta dilengkapi dengan mekanisme efektif untuk berbagi dan mengkomunikasikan rancangan mereka dengan yang lain (Munawar, 2005).

UML memiliki beberapa diagram yang mampu membantu pengembang mengkomunikasikan sistem yang akan mereka buat, diagram-diagram tersebut antara lain adalah use case, class diagram, dan sequence diagram.

\section{1) Use case diagram}

Use case merupakan penjelasan fungsi dari sebuah sistem melalui perspektif pengguna. Use case bekerja dengan cara mendeskripsikan jenis interaksi antara user (actor) dengan sistemnya sendiri melalui sebuah cerita bagaimana sebuah sistem dipakai. Urutan langkah-langkah yang menerangkan hubungan antar actor dengan sistem disebut dengan scenario yang digabungkan bersama-sama oleh tujuan umum pengguna (Munawar, 2005).

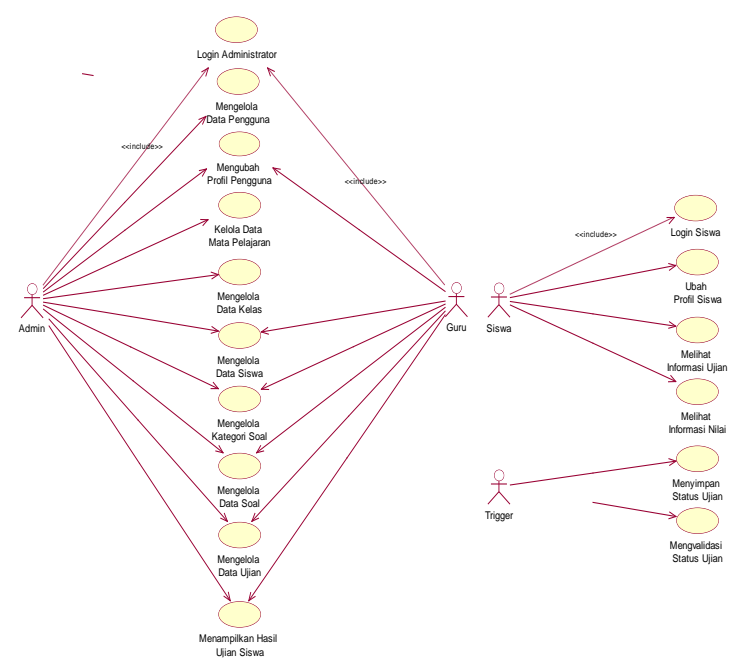

Gambar 3. Use case diagram

\section{2) Class diagram}

Class diagram merupakan representasi sebuah gambar yang memperlihatkan attribut atau property serta operasi yang dimiliki oleh suatu objek dan menggambarkan hubungan objek lainnya. Class biasanya digunakan untuk mendefinisikan objek-objek bisnis. Class seperti ini biasanya mendefinisikan model database dari suatu aplikasi (Munawar, 2005). 


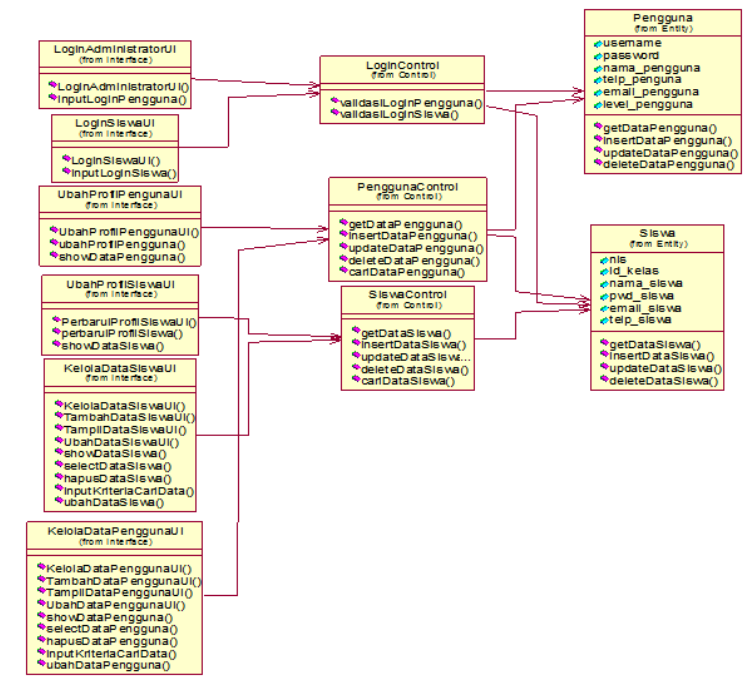

Gambar 5. class diagram

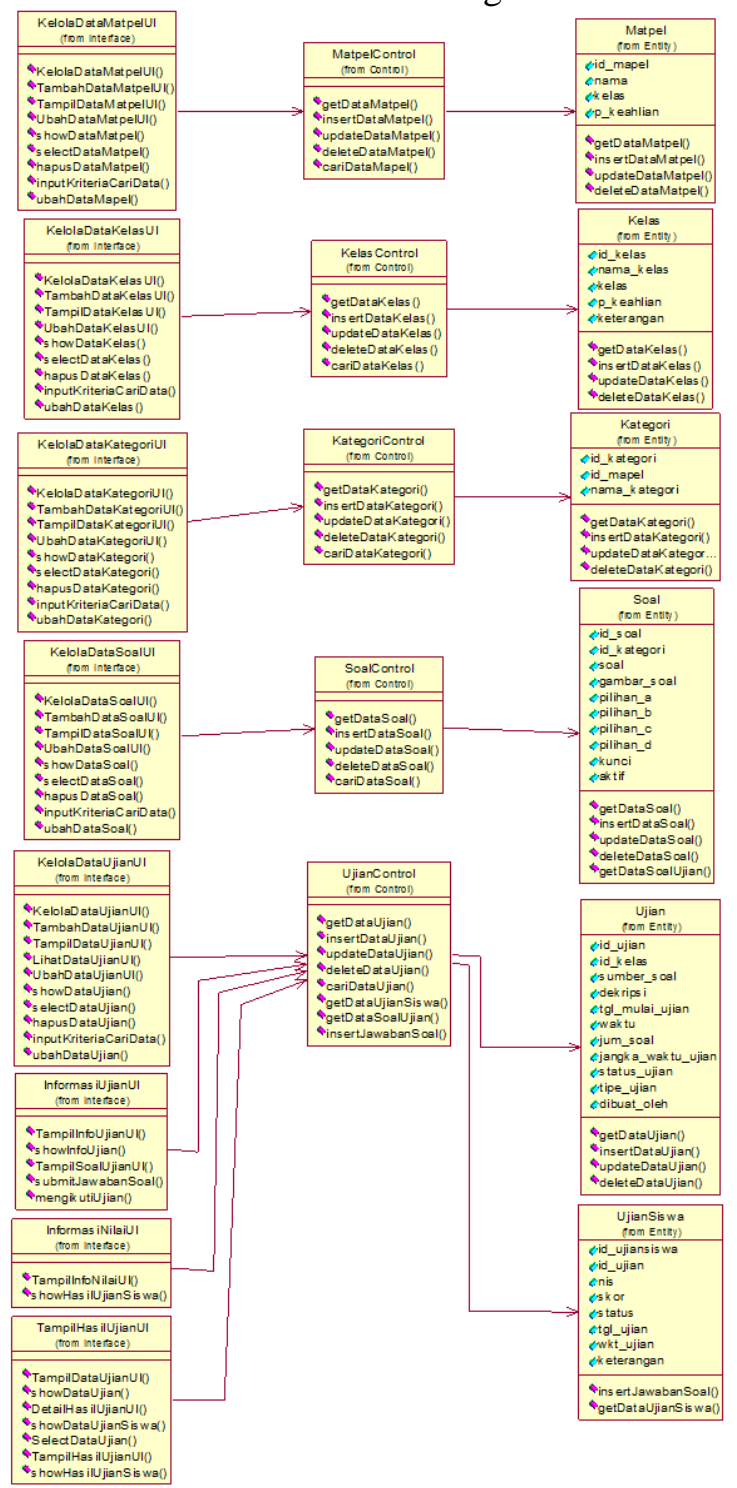

Gambar 6. class diagram (lanjutan)
Irwanto (2006) menyatakan bahwa digunakannya sequence diagram karena kita ingin melihat rangkaian urut-urutan event yang terjadi. Pada fase tersebut kita masih dimungkinkan untuk melakukan pemeriksaan secara literasi operasi-operasi dan atribut-atribut yang masih kurang. Jika ditemukan masih ada operasi yang kurang, maka tambahkan operasi tersebut ke dalam ke dalam class diagram.

4) Desain basis data

Berdasarkan class diagram maka dapat dibentuk 8 tabel. Berikut ini adalah rincian tabel-tabel yang dihasilkan.

Tabel 1. Tabel pengguna

\begin{tabular}{|l|l|r|}
\hline Nama & Tipe & Panjang \\
\hline username & varchar & 30 \\
\hline password & varchar & 50 \\
\hline nama_pengguna & varchar & 40 \\
\hline telp_pengguna & varchar & 12 \\
\hline email_pengguna & varchar & 30 \\
\hline level_pengguna & varchar & 10 \\
\hline
\end{tabular}

Tabel 2. Tabel kelas

\begin{tabular}{|l|l|r|}
\hline Nama & Tipe & Panjang \\
\hline id_kelas & int & 6 \\
\hline nama_kelas & varchar & 40 \\
\hline kelas & int & 2 \\
\hline p_keahlian & varchar & 3 \\
\hline keterangan & text & - \\
\hline
\end{tabular}

Tabel 3. Tabel mata pelajaran

\begin{tabular}{|l|l|r|}
\hline Nama & Tipe & Panjang \\
\hline id_mapel & int & 5 \\
\hline nama_mapel & varchar & 40 \\
\hline kelas & int & 2 \\
\hline p_keahlian & varchar & 3 \\
\hline
\end{tabular}

Tabel 4. Tabel siswa

\begin{tabular}{|l|l|r|}
\hline Nama & Tipe & Panjang \\
\hline nis & int & 5 \\
\hline id_kelas & int & 6 \\
\hline nama_siswa & varchar & 40 \\
\hline pwd_siswa & varchar & 50 \\
\hline email_siswa & varchar & 30 \\
\hline telp_siswa & varchar & 12 \\
\hline
\end{tabular}

Tabel 5. Tabel kategori soal \begin{tabular}{|l|l|l|}
\hline Nama & Tipe & Panjang \\
\hline
\end{tabular} 


\begin{tabular}{|l|l|r|}
\hline id_kategori & int & 5 \\
\hline id_mapel & int & 5 \\
\hline nama_kategori & varchar & 35 \\
\hline
\end{tabular}

Tabel 6. Tabel soal

\begin{tabular}{|l|l|r|}
\hline Nama & Tipe & Panjang \\
\hline id_soal & int & 10 \\
\hline id_kategori & int & 5 \\
\hline soal & text & - \\
\hline gambar_soal & varchar & 70 \\
\hline pilihan_a & text & - \\
\hline pilihan_b & text & - \\
\hline pilihan_c & text & - \\
\hline pilihan_d & text & - \\
\hline pilihan_e & text & - \\
\hline kunci & varchar & 2 \\
\hline aktif & varchar & 2 \\
\hline
\end{tabular}

Tabel 7. Tabel ujian

\begin{tabular}{|l|l|r|}
\hline Nama & Tipe & Panjang \\
\hline id_ujian & int & 10 \\
\hline id_kelas & int & 6 \\
\hline sumber_soal & int & 5 \\
\hline deskripsi & varchar & 40 \\
\hline tgl_mulai_ujian & date & - \\
\hline waktu & varchar & 8 \\
\hline jum_soal & int & 5 \\
\hline jangka_waktu_ujian & date & - \\
\hline status_ujian & varchar & 30 \\
\hline tipe_ujian & varchar & 10 \\
\hline dibuat_oleh & varchar & 30 \\
\hline
\end{tabular}

Tabel 8. Tabel ujian siswa

\begin{tabular}{|l|l|r|}
\hline Nama & Tipe & Panjang \\
\hline id_ujiansiswa & int & 10 \\
\hline id_ujian & int & 10 \\
\hline nis & int & 5 \\
\hline skor & int & 10 \\
\hline status & varchar & 15 \\
\hline tgl_ujian & date & - \\
\hline wkt_ujian & int & - \\
\hline keterangan & varchar & 45 \\
\hline
\end{tabular}

\section{HASIL DAN PEMBAHASAN}

\section{A. Arsitektur perangkat lunak}

Sistem ujian online merupakan sebuah perangkat lunak yang digunakan untuk membantu siswa melaksanakan ujian pada SMK Informatika Uyelindo Kupang. Sistem ujian ini dibuat menggunakan framework codeigniter yang menerapkan Model, View, Controller (MVC), PHP
(Hypertext Preprocessor) sebagai bahasa pemrograman dan MySQL sebagai Database Management System (DBMS).

Pada sistem ini arsitektur perangkat lunak yang digunakan berupa web database server, dimana segala permintaan (request) pengguna diproses oleh web server dan semua data tersimpan pada database server. Pengguna sistem yakni administrator dan siswa dapat mengakses sistem ujian online melalui browser pada personal computer (PC) atau notebook yang terhubung dengan jaringan internet melalui modem atau wi-fi. Web server akan memproses data pada database server ketika pengguna melakukan permintaan ke sistem ujian online.

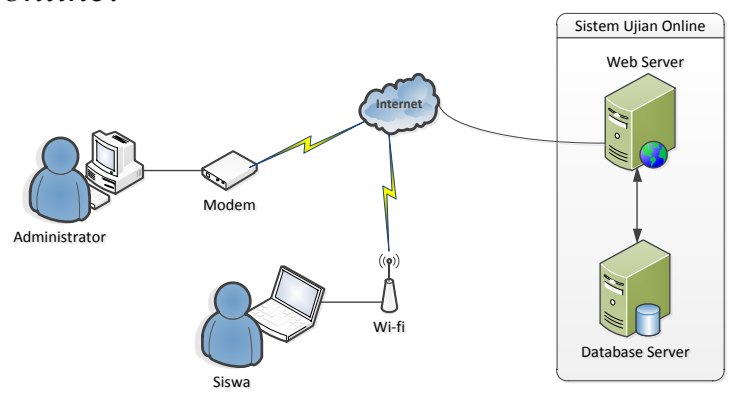

Gambar 7. Arsitektur sistem ujian online

\section{B. Rekomendasi server}

Perangkat lunak sistem ujian online ini pada realisasinya akan diakses oleh guru dan para siswa. Hal tersebut akan meningkatkan traffic ketika mengakses sistem ini dan berpotensi mengakibatkan sistem menjadi down. Maka dari itu, rekomendasi server yang bisa disarankan untuk sistem ujian online sebagai berikut :

Tabel 9. Rekomendasi server

\begin{tabular}{|c|l|l|}
\hline No & \multicolumn{1}{|c|}{ Komponen } & \multicolumn{1}{|c|}{ Rekomendasi } \\
\hline 1. & Server Host & Server IIX \\
\hline 2. & Disk space & 1 GB \\
\hline 3. & Bandwitdh & 50 GB \\
\hline 4. & Web server & LiteSpeed Web Server \\
\hline 5. & PHP support & PHP 5.3.x Support \\
\hline 6. & Database & MySQL 5 Databases \\
\hline
\end{tabular}

\section{Antarmuka sistem}

1) Halaman login

Halaman login administrator adalah halaman yang ditampilkan pada saat 
halaman administrator diakses pertama kali oleh pengguna (pengguna belum melakukan login pada sistem). Pada halaman ini, pengguna harus mengisi username dan password yang sudah terdaftar dalam database system.

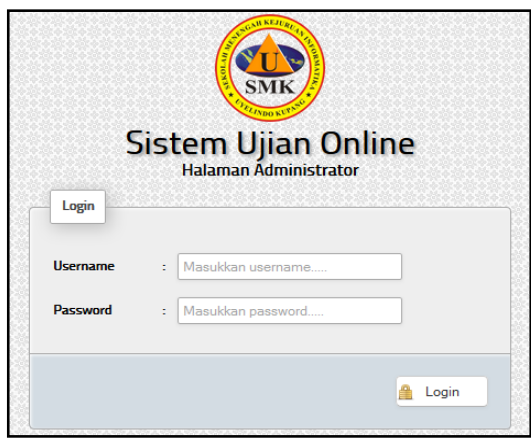

Gambar 8. Halaman login administrator

Halaman utama administrator adalah halaman utama ketika pengguna berhasil login ke dalam sistem. Pada halaman ini, terdapat menu yang terdapat pada sisi kiri halaman. Ada 2 jenis administrator, yakni halaman administrator yang diakses oleh pengguna dengan level admin dan level guru.

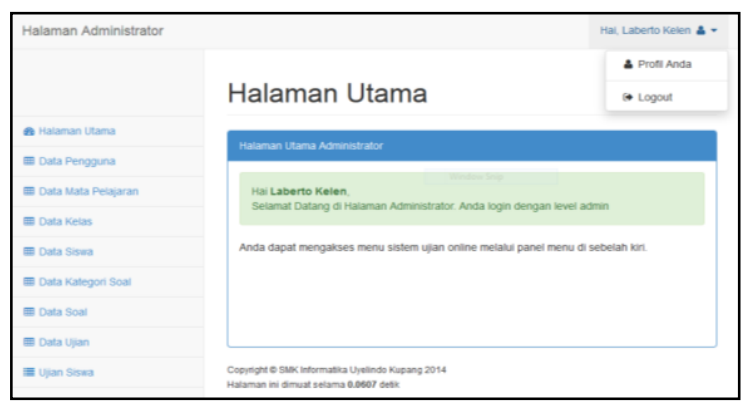

Gambar 9. Halaman utama admin

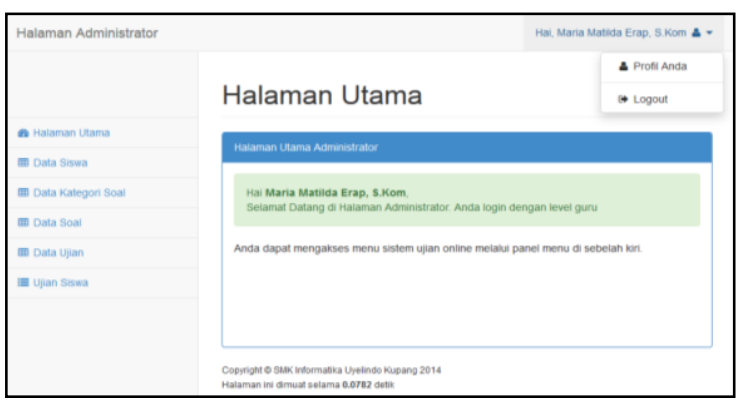

Gambar 10. Halaman utama guru

Halaman login siswa adalah halaman yang ditampilkan pada saat halaman siswa diakses pertama kali oleh siswa (siswa belum melakukan login pada sistem). Pada halaman ini, siswa harus mengisi Nomor Induk Siswa (NIS) dan password yang sudah terdaftar dalam database sistem.

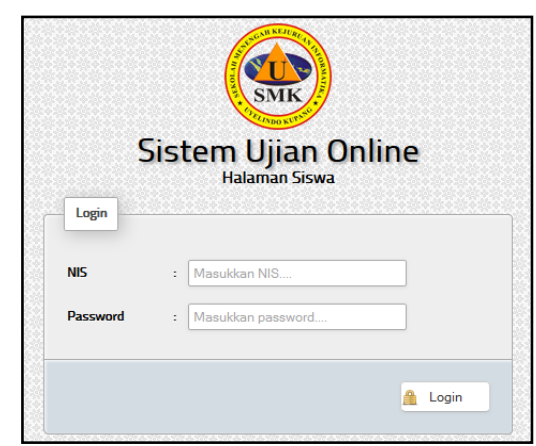

Gambar 11. Halaman login siswa

\section{2) Halaman ujian}

Halaman informasi ujian adalah halaman yang menampilkan informasi ujian yang telah dibuat kepada siswa. Siswa dapat mengklik tombol lihat info ujian untuk melihat informasi detail ujian.

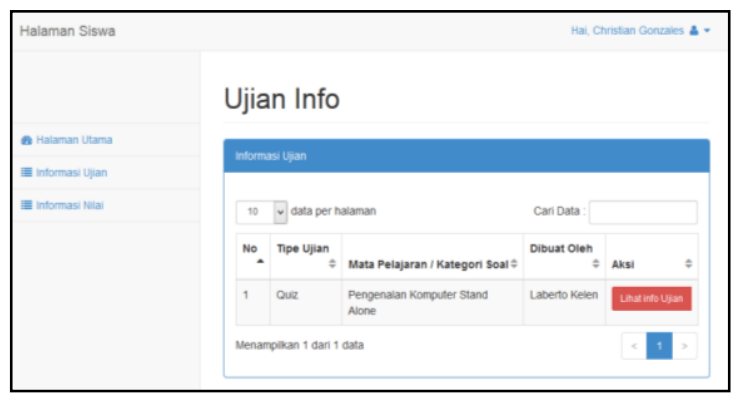

Gambar 12. Halaman ujian yang tersedia

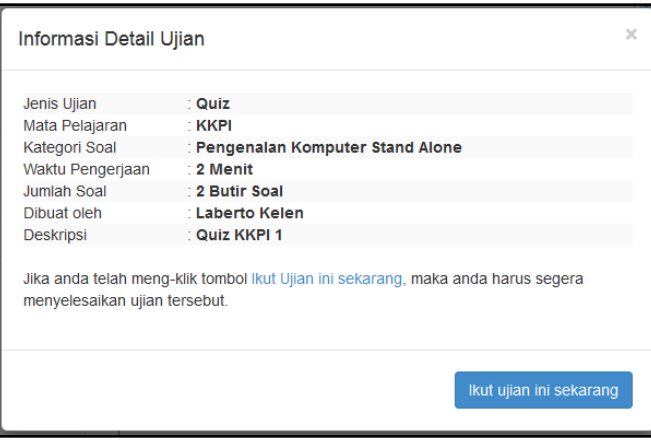

Gambar 13. Konfirmasi mengikuti ujian

Halaman soal ujian adalah halaman yang menampilkan soal-soal ujian. Halaman ini diciptakan otomatis sesuai jenis ujian (exam/quiz) dan soal-soal yang disajikan 
kepada siswa ditampilkan secara acak (random).

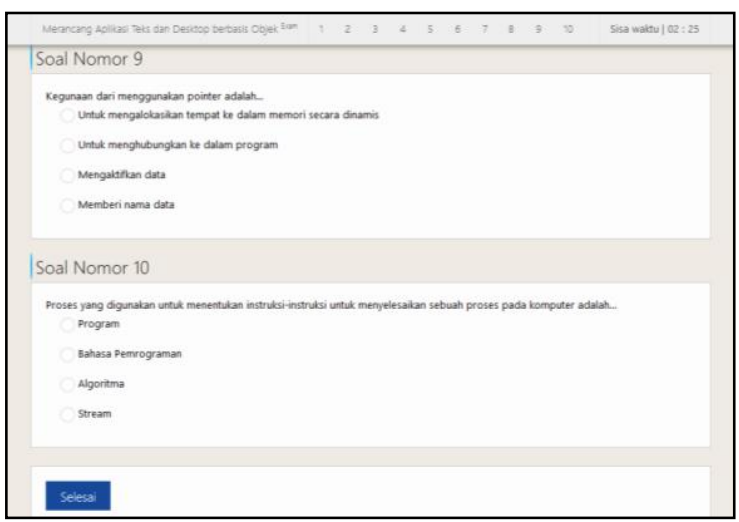

Gambar 14. Tampilan lembar soal ujian ketika diakses

\section{KESIMPULAN}

Pada tahapan implementasi MVC pada sistem ujian online dengan framework codeigniter ini membuat pelaksanaan ujian pada SMK Informatika Uyelindo Kupang menjadi lebih mudah dan fleksibel karena siswa bisa melakukan ujian dari mana saja dan sesuai waktu yang ditetapkan guru. Penerapan sistem ini diharapkan dapat meminimalisir penggunaan kertas dalam pelaksanaan ujian.

\section{DAFTAR PUSTAKA}

[1] Peranginangin, Kasiman, Aplikasi Web dengan PHP dan MySQL, Penerbit Andi, Yogyakarta, 2006.

[2] Kadir, Abdul, Mudah Mempelajari Database MySQL, Penerbit Andi, Yogyakarta, 2010.

[3] Harianja, Jhonson P., Sistem Ujian Adaptif untuk Seleksi Penerimaan Mahasiswa Baru pada Perguruan Tinggi Berbasis Web melalui Penerapan Teknik MVC dengan menggunakan PHP Framework Codeigniter, Universitas Maritim Raja Ali Haji, Jurnal, 2010.

[4] Sidik, Betha, Framework CodeIgniter, Penerbit Informatika, Bandung, 2012.

[5] Munawar, Pemodelan Visual dengan UML, Penerbit Graha Ilmu, Yogyakarta, 2005.

[6] Irwanto, Djon, Perancangan Object Oriented Software dengan UML, Penerbit Andi, Yogyakarta, 2006. 